\title{
The effect of Helicobacter pylori eradication on proteinuria in patients with primary glomerulonephritis
}

Fatih Dede ${ }^{1}$, Deniz Ayli ${ }^{1}$, Ipek Gonul'2, Osman Yuksel ${ }^{3}$, Ramazan Ozturk ${ }^{1}$, Ayla Yildiz ${ }^{3}$, Ezgi Yenigun ${ }^{1}$, Serhan Piskinpasa ${ }^{1}$, Didem Turgut ${ }^{1}$, Eyup Koc ${ }^{1}$, Ali Riza Odabas ${ }^{1}$

1Department of Nephrology, Ankara Numune Training and Research Hospital, Ankara, Turkey

2Department of Pathology, Gazi University, Faculty of Medicine, Ankara, Turkey 3Department of Gastroenterology, Ankara Numune Training and Research Hospital, Ankara, Turkey

Submitted: 21 July 2011

Accepted: 19 October 2011

Arch Med Sci 2015; 11, 4: 764-769

DOI: 10.5114 /aoms.2013.37013

Copyright @ 2015 Termedia \& Banach

\section{Abstract}

Introduction: Glomerulonephritis is still the primary cause among the diseases causing end stage renal disease. Helicobacter pylori (HP), also having a local proinflammatory effect on gastric mucosa, can trigger a local and systemic inflammatory response, and consequently have a role in the development of extragastrointestinal defects.

Material and methods: The study was composed of patients diagnosed with primary glomerulonephritis who had dyspeptic complaints throughout the diagnosis. Patients who received endoscopic biopsy upon the determination of pathologic findings in their upper gastrointestinal endoscopy were HP positive in their biopsy material. A triple eradication therapy was initiated for HP.

Results: The study included 14 female and 19 male patients, 33 in total, whose biopsy material was determined to be HP positive. Before the eradication for $\mathrm{HP}$, we found serum albumin to be $34.0(19.0-51.0) \mathrm{g} / \mathrm{l}$, serum total protein 58.6 $\pm 12.9 \mathrm{~g} / \mathrm{l}$, serum creatinine $0.9(0.5-1.2)$ and proteinuria 3069 (652-12392) $\mathrm{mg} /$ day in 24-hour urine. After the eradication, however, serum albumin was found to be $40(20-52) \mathrm{g} / \mathrm{l}$, serum total protein $62.3 \pm 11.1 \mathrm{~g} / \mathrm{l}$, serum creatinine $1.02(0.6-1.29) \mathrm{mg} / \mathrm{dl}$ and proteinuria was 2850 (172-15181) $\mathrm{mg} /$ day in 24-hour urine. A comparison of the results showed that a statistically significant difference is established between the serum albumin, total protein and creatinine values ( $p=0.001, p=0.001$ and $p=0.021$, respectively), but not between proteinuria values in 24-hour urine $(p=0.990)$.

Conclusions: Patients with primary glomerulonephritis, HP eradication treatment has an effect on serum albumin levels.

Key words: glomerulonephritis, Helicobacter pylori, proteinuria.

\section{Introduction}

Glomerulonephritis, which may develop due to diverse reasons such as infections, collagen vascular diseases, malignancies or drugs, is among the leading diseases causing end-stage renal disease (ESRD) development. Sufficient progress has not yet been made in its long-term treatment. Primary glomerulonephritis consists of different histopathological subgroups presenting similar clinical properties. Membranous glomerulonephritis (MGN) is described as homogeneous thickening of the capillary wall and

\author{
Corresponding author: \\ Assoc. Prof. Fatih Dede \\ Ankara Numune Egitim \\ ve Arastırma Hastanesi \\ Nefroloji Klinigi \\ Samanpazari, Ankara \\ 06530, Turkey \\ Phone: +90 312508 4553, \\ $-4552,-4557$ \\ Fax: +90 3123104616 \\ E-mail: fatded@yahoo.com
}


granular subepithelial deposits of IgG and C3. IgA nephropathy (IgAN) is defined as increased mesangial cellularity and mesangial deposition of IgA. Focal segmental glomerulosclerosis (FSGS) is characterized as segmental and/or focal sclerosis of glomeruli with or without hyalinosis and endocapillary hypercellularity. Mesangioproliferative glomerulonephritis (MzPGN) is described as increased mesangial cellularity and mesangial deposition of IgM and C3 without IgA. Membranoproliferative glomerulonephritis (MPGN) is defined as accumulation of extracellular material, a double contouring of the glomerular basal membrane, increased mesangial cellularity and IgM, IgG, and C3 in a glomerular capillary wall and mesangial areas [1-3]. Even though the pathogenesis of the disease includes various cytokines distorting glomerular basal membrane permeability and the resulting inflammatory process, cellular and humoral immune system activation and genetic factors, the immunologic mechanism of primary glomerulonephritis and the factors that trigger it have not been entirely enlightened [2].

Helicobacter pylori (HP) is a chronic infection closely related to numerous gastrointestinal diseases such as peptic ulcer, gastric adenoma and cancer $[4,5]$. The reported prevalence of HP in the adult population is $67.6-81.3 \%$ in our country [6]. Although limited to the gastric mucosa, HP can trigger a local and systemic inflammatory response and consequently play a part in the development of various extragastrointestinal disorders [7-10]. The bacterial peptides of HP are considered to be effective in the pathogenesis of those diseases by chronically stimulating the immune system in various mechanisms. Gastric mucosa infected by HP stimulates the release of proinflammatory cytokines such as tumor necrosis factor $\alpha$ (TNF- $\alpha$ ), interferon $\gamma($ IFN- $\gamma$ ), interleukin-1 (IL-1), IL-6, IL-8, IL-10 and IL-12. It also triggers the cellular and humoral immune system and causes specific immune cell activation. Also it increases cytokines derived from mononuclear macrophages, stimulates neutrophil chemotaxis and its activation, and increases the expression and degranulation of adhesion molecules and the production of reactive oxygen metabolites. Therefore, it also stimulates specific immunity $[4,7,11]$. This local proinflammatory effect that HP has on gastric mucosa was thought to have a potential systemic effect and activate the immune response. Following the discovery of HP, its relation to pathologies such as thrombocytopenic purpura, coronary artery disease, respiratory disorders, iron deficiency, anemia and urticaria was studied [4, 7, $8,10,12]$.

In this study, we investigated the effect of HP eradication therapy on the remission of the disease in patients with primary glomerulonephritis and gastritis and peptic ulcer-like dyspeptic complaints who received upper gastrointestinal endoscopy resulting in the determination of pathology and HP diagnosis in their biopsy.

\section{Material and methods}

Of the 144 patients who applied to our hospital with proteinuria and were diagnosed with glomerulonephritis between December 2006 and January 2009 , those with primary glomerulonephritis whose advanced tests excluded secondary reasons (systemic lupus erythematosus and other collagen vascular diseases, vasculitis, diabetes mellitus, amyloidosis, malignancies, drug-induced glomerulonephritis and concomitant glomerulonephritis to systemic diseases) were admitted to the study. Before the study, all the patients were informed about the process and treatment that would be applied throughout the study and their approval was received.

Of these 144 patients who were diagnosed with primary glomerulonephritis, 43 who had dyspeptic complaints at the time of diagnosis were prepared for upper gastrointestinal endoscopy. Thirty-nine patients who showed pathologic findings in endoscopy also received endoscopic biopsy, and HP was studied in the biopsy material. All patients who underwent biopsy received urea breath test simultaneously. A total of 33 patients whose biopsy material was found to be HP positive were studied and triple eradication therapy was started. The treatment involved omeprazole $40 \mathrm{mg} /$ day, amoxycillin 2000 mg/day and clarithromycin 1000 mg/day for 14 days duration. Patients' pre- and post-treatment biochemical parameters and proteinuria values were compared. The control of HP existence after triple eradication was made by urea breath test 3 weeks after the treatment. The process was repeated in 3 patients who were still positive in the urea breath test following eradication, and their biochemical data were obtained after negative urea breath test upon the consecutive treatment.

Blood samples were obtained from all participants via antecubital venipuncture by trained medical personnel in the fasting state. The blood and urine samples were analyzed on the same day without delay. A 24-hour urine was collected for the measurement of albumin and protein excretion rate in all subjects. Blood creatinine, protein, albumin, lipid parameters and urine creatinine and protein were analyzed with spectrophotometric methods; C-reactive protein (CRP) was analyzed with turbidimetric methods with a multichannel Synchron DxC 800 analyzer (Beckman Coulter, USA) [13]. Urea breath test was applied with $1 \mu \mathrm{Ci} 14 \mathrm{C}$-Urea capsules (Helicap, Heliprobe Breath Card, Kibion Ab, Uppsala, Sweden) [14]. Ultrasonography guided renal biopsies were performed with 16 gauge nee- 
Table I. Demographic features of patients

\begin{tabular}{|lc|}
\hline Variable & All patients \\
\hline Number of patients, $n$ (\%) & $33(100)$ \\
\hline Male/female, $n$ (\%) & $19(57) / 14(43)$ \\
\hline Age [years] & $31.5 \pm 9.2$ \\
\hline Age (male/female) [years] & $32 \pm 8.9 / 30.8 \pm 9.7$ \\
\hline \begin{tabular}{l} 
Subtype of glomerulonephritis, $n$ (\%) \\
\hline IgA nephropathy
\end{tabular} & $7(21.3)$ \\
\hline Membranous glomerulonephritis & $6(18.2)$ \\
\hline $\begin{array}{l}\text { Mesangioproliferative } \\
\text { glomerulonephritis }\end{array}$ & $5(15.1)$ \\
\hline $\begin{array}{l}\text { Membranoproliferative } \\
\text { glomerulonephritis }\end{array}$ & $5(15.1)$ \\
\hline Focal segmental glomerulosclerosis & $15(45.5)$ \\
\hline \begin{tabular}{l} 
Endoscopic findings, $n$ (\%) \\
\hline Antral gastritis
\end{tabular} & $13(39.4)$ \\
\hline $\begin{array}{l}\text { Pangastritis } \\
\text { Erosive gastritis }\end{array}$ & $3(6)$ \\
\hline
\end{tabular}

Continuous variables are reported as mean (standard deviation) for normally distributed data or median (interquartile range) for asymmetrically distributed data. Categorical variables are reported as number (percentage)

dles. Upper endoscopy was performed with FujinonEG450WR5 type gastroscopy and biopsies - four in number - from the antrum and corpus were taken with forceps for HP histopathological diagnosis.

During the eradication treatment, all patients ( $n=33$ ) were administered ramipril $2.5-5 \mathrm{mg} /$ day (based on their arterial pressure follow-up), aspirin $100 \mathrm{mg} /$ day and lipid-lowering drugs (if necessary). Patients were on a protein $(0.6-0.8 \mathrm{~g} / \mathrm{kg} /$ day $)$ and salt (4-6 g/day sodium) restricted diet during the entire treatment.

Nephrotic range proteinuria was described as $3.5 \mathrm{~g} /$ day creatinine or higher proteinuria. Renal failure was defined as serum creatinine above $1.3 \mathrm{mg} / \mathrm{dl}$, hypoalbuminemia was defined as $35 \mathrm{~g} / \mathrm{l}$ below the value of serum albumin. Patients who were shown to have malignancies, diabetes mellitus, liver disease, stage 3-4 cardiac failure, or acute coronary syndrome, pregnancy or active infection within the last 2 months were excluded. Likewise, patients with renal lesion and/or hypertension at the time of diagnosis, those with a history of acidsuppressive drug use within the last 6 months, those with a history of upper gastrointestinal system disease or surgery, and those who previously received eradication therapy due to HP were not included in the study. None of the patients had been previously treated with immunosuppressive agents. The study protocol was approved by the local ethics committee.

\section{Statistical analysis}

All analyses were performed using the SPSS 15.0 package (SPSS Inc., Chicago, IL) for Windows. While data with normal distribution were given as mean \pm standard deviation, data without normal distribution were given as median (minimum-maximum). In data analysis, the Wilcoxon test for the comparison of medians in dependent groups, Student $t$-test for the comparison of averages, and nonparametric tests were used. For all statistical tests, a $p$ value under 0.05 was considered significant.

\section{Results}

The study included 33 patients in total, 19 male and 14 female, whose biopsy material was determined to be HP positive. As the primary glomerulonephritis subgroup, we found IgAN in 10 (30.3\%), MGN in 7 (21.3\%), MzPGN in 6 (18.2\%), FSGS in 5 (15.1\%), and MPGN in 5 (15.1\%) patients. The mean age of patients was $31.5 \pm 9.2$ years. While patients' hepatitis B and C virus antigen and antibody levels and serum autoantibody levels were all negative, their complement levels were within normal limits. HP was positive in $76.7 \%$ (33/43) of the patients who had dyspeptic complaints and pathology. The most common endoscopic finding found in the patients was antral gastritis and pangastritis. While 15 (45.5\%) had antral gastritis and 13 (39.4\%) had pangastritis, 3 (9.1\%) had bulbitis and $2(6 \%)$ had erosive gastritis. The general characteristics of patients before eradication and their laboratory data are given in Table I. In endoscopic biopsy materials, the histopathologic finding in all patients was coherent with chronic gastritis. Urea breath test before eradication was positive in 29 of the 33 patients. After eradication, the urea breath test of 3 patients was still positive. A second triple eradication therapy was administered in those patients, after which control urea breath tests were found to be negative. Before the HP eradication treatment, the serum albumin value was 34.0 (19.0$51.0) \mathrm{g} / \mathrm{l}$, serum total protein was $58.6 \pm 12.9 \mathrm{~g} / \mathrm{l}$, serum creatinine was $0.9(0.5-1.2) \mathrm{mg} / \mathrm{dl}$ and proteinuria in 24-hour urine was 3069 (652-12392) $\mathrm{mg} /$ day. After the eradication, however, serum albumin was $40(20-52) \mathrm{g} / \mathrm{l}$, serum total protein was $62.3 \pm 11.1 \mathrm{~g} / \mathrm{l}$, serum creatinine was 1.02 (0.6-1.29) $\mathrm{mg} / \mathrm{dl}$ and proteinuria in 24-hour urine was 2850 (172-15181) mg/day. When the results were compared, there was a statistically significant difference between the values of serum albumin, total protein and creatinine ( $p=0.001, p=0.001$ and $p=0.021$, respectively), while there was not any statistical difference between proteinuria values of 24-hour urine ( $p=0.990)$ (Table II). Despite the statistically significant increase in serum creatinine values, the serum creatinine values of all patients 
Table II. Findings before and after Helicobacter pylori eradication treatment

\begin{tabular}{|lccc|}
\hline Variable & Before treatment & After treatment & Value of $p$ \\
\hline Serum creatinine $[\mathrm{mg} / \mathrm{dl}]$ & $0.9(0.5-1.20)$ & $1.02(0.6-1.29)$ & 0.021 \\
\hline Serum total protein $[\mathrm{g} / \mathrm{l}]$ & $58.6 \pm 12.9$ & $62.3 \pm 11.1$ & 0.001 \\
\hline Serum albumin $[\mathrm{g} / \mathrm{l}]$ & $34.0(19.0-51.0)$ & $40(20-52)$ & 0.001 \\
\hline Proteinuria $[\mathrm{g} / \mathrm{day}]$ & $3069(652-12392)$ & $2850(172-15181)$ & 0.990 \\
\hline Serum total cholesterol $[\mathrm{mg} / \mathrm{dl}]$ & $246.6 \pm 89.2$ & $227 \pm 64.3$ & 0.460 \\
\hline Serum triglyceride $[\mathrm{mg} / \mathrm{dl}]$ & $156(55-464)$ & $154(51-356)$ & 0.640 \\
\hline Serum LDL $[\mathrm{mg} / \mathrm{dl}]$ & $148(65-404)$ & $143(78-268)$ & 0.124 \\
\hline Serum HDL $[\mathrm{mg} / \mathrm{dll}]$ & $45.9 \pm 10.1$ & $50.6 \pm 14.0$ & 0.190 \\
\hline hsCRP $[\mathrm{mg} / \mathrm{l}]$ & $2.94(0.4-4.6)$ & $3.14(0.7-4.2)$ & 0.560 \\
\hline
\end{tabular}

${ }^{*}$ Continuous variables are reported as mean (standard deviation) for normally distributed data or median (interquartile range) for asymmetrically distributed data

were within normal limits after HP eradication. Lipid parameters before and after HP eradication were not statistically significant. The same follow-up parameters in the glomerulonephritis subgroups yielded similar results. Other than the serum creatinine values of MzPGN patients ( $p=0.027)$, sta- tistically significant differences were not observed in the comparison of any of the parameters (Table III). In 5 of the 33 patients (IgAN in 3 patients, MGN in 1 patient, MPGN in 1 patient), there was a significant decrease in proteinuria after HP eradication (Table IV).

Table III. Findings of glomerulonephritis subtypes before and after Helicobacter pylori eradication treatment

\begin{tabular}{|c|c|c|c|c|c|c|c|c|c|}
\hline \multirow[t]{2}{*}{$\begin{array}{l}\text { Subtype } \\
\text { of GN }\end{array}$} & \multirow[t]{2}{*}{$N$} & \multicolumn{2}{|c|}{$\begin{array}{l}\text { Proteinuria } \\
\text { [g/day] }\end{array}$} & \multicolumn{2}{|c|}{$\begin{array}{l}\text { Serum albumin } \\
{[\mathrm{g} / \mathrm{l}]}\end{array}$} & \multicolumn{2}{|c|}{$\begin{array}{l}\text { Serum total protein } \\
{[\mathrm{g} / \mathrm{l}]}\end{array}$} & \multicolumn{2}{|c|}{$\begin{array}{l}\text { Serum creatinine } \\
{[\mathrm{mg} / \mathrm{dl}]}\end{array}$} \\
\hline & & BT & AT & BT & AT & BT & AT & BT & AT \\
\hline IgAN & 10 & $\begin{array}{c}5048 \\
(652-12392)\end{array}$ & $\begin{array}{c}3040 \\
(172-8094)\end{array}$ & $\begin{array}{c}39.2 \\
(25-51)\end{array}$ & $\begin{array}{c}41.3 \\
(24-52)\end{array}$ & $\begin{array}{c}64.9 \\
(53-80)\end{array}$ & $\begin{array}{c}67.3 \\
(54-81)\end{array}$ & $\begin{array}{c}1.04 \\
(0.72-1.20)\end{array}$ & $\begin{array}{c}1.07 \\
(0.70-1.29)\end{array}$ \\
\hline MGN & 7 & $\begin{array}{c}6156 \\
(2500-8588)\end{array}$ & $\begin{array}{c}7027 \\
(1560-15181)\end{array}$ & $\begin{array}{c}28.7 \\
(25-34)\end{array}$ & $\begin{array}{c}33.1 \\
(25-41)\end{array}$ & $\begin{array}{c}47.4 \\
(36-65)\end{array}$ & $\begin{array}{c}55.6 \\
(48-66)\end{array}$ & $\begin{array}{c}0.87 \\
(0.54-1.27)\end{array}$ & $\begin{array}{c}0.90 \\
(0.65-1.20)\end{array}$ \\
\hline MzPGN & 6 & $\begin{array}{c}2254 \\
(814-4365)\end{array}$ & $\begin{array}{c}2187 \\
(654-4500)\end{array}$ & $\begin{array}{c}39.5 \\
(26-50)\end{array}$ & $\begin{array}{c}41.7 \\
(27-52)\end{array}$ & $\begin{array}{c}64.7 \\
(48-77)\end{array}$ & $\begin{array}{c}66.1 \\
(50-80)\end{array}$ & $\begin{array}{c}0.74^{\star} \\
(0.50-0.92)\end{array}$ & $\begin{array}{c}0.84^{\star *} \\
(0.60-1.03)\end{array}$ \\
\hline MPGN & 5 & $\begin{array}{c}3726 \\
(1532-6300)\end{array}$ & $\begin{array}{c}3273 \\
(1350-5460)\end{array}$ & $\begin{array}{c}40.0 \\
(31-47)\end{array}$ & $\begin{array}{c}42.4 \\
(30-49)\end{array}$ & $\begin{array}{c}62.2 \\
(47-73)\end{array}$ & $\begin{array}{c}63.6 \\
(51-74)\end{array}$ & $\begin{array}{c}0.93 \\
(0.70-1.07)\end{array}$ & $\begin{array}{c}0.96 \\
(0.70-1.20)\end{array}$ \\
\hline FSGS & 5 & $\begin{array}{c}4020 \\
(1050-10800)\end{array}$ & $\begin{array}{c}5037 \\
(2152-9586)\end{array}$ & $\begin{array}{c}40.0 \\
(27-46)\end{array}$ & $\begin{array}{c}40.5 \\
(26-47)\end{array}$ & $\begin{array}{c}60.3 \\
(43-68)\end{array}$ & $\begin{array}{c}62.3 \\
(48-73)\end{array}$ & $\begin{array}{c}1.10 \\
(0.90-1.20)\end{array}$ & $\begin{array}{c}1.17 \\
(1.08-1.20)\end{array}$ \\
\hline
\end{tabular}

AT - after treatment, BT - before treatment, FSGS - focal segmental glomerulosclerosis, GN - glomerulonephritis, IgAN - IgA nephropathy, MGN - membranous glomerulonephritis, MPGN - membranoproliferative glomerulonephritis, MzPGN - mesangioproliferative glomerulonephritis *When the values of each group after Helicobacter pylori treatment were compared, statistically significant differences were not found in any parameter other than the creatinine values of MzPGN patients $(p=0.027)$. ${ }^{* *}$ Continuous variables are reported as median (interquartile range) for data.

Table IV. Characteristics of patients who displayed significant regression in proteinuria after Helicobacter pylori eradication treatment

\begin{tabular}{|c|c|c|c|c|c|c|c|c|c|c|}
\hline $\begin{array}{l}\text { Patient } \\
\text { number }\end{array}$ & $\begin{array}{c}\text { Age } \\
\text { [years] }\end{array}$ & Gender & $\begin{array}{l}\text { Subtype } \\
\text { of GN }\end{array}$ & $\begin{array}{c}\mathrm{Hb} \\
{[\mathrm{g} / \mathrm{dl}]}\end{array}$ & $\begin{array}{l}\text { Creatinine } \\
\text { [mg/dl] (BT) }\end{array}$ & $\begin{array}{l}\text { Creatinine } \\
\text { [mg/dl] (AT) }\end{array}$ & $\begin{array}{l}\text { Albumin } \\
{[\mathrm{g} / \mathrm{l}](\mathrm{BT})}\end{array}$ & $\begin{array}{l}\text { Albumin } \\
{[\mathrm{g} / \mathrm{l}](\mathrm{AT})}\end{array}$ & $\begin{array}{c}\text { Proteinuria } \\
\text { [mg/day] (BT) }\end{array}$ & $\begin{array}{c}\text { Proteinuria } \\
\text { [mg/day] (AT) }\end{array}$ \\
\hline 1 & 38 & $\mathrm{~F}$ & IgAN & 12.4 & 1.20 & 1.10 & 26 & 24 & 11700 & 1287 \\
\hline 2 & 35 & $\mathrm{~F}$ & IgAN & 12.1 & 0.77 & 0.97 & 25 & 28 & 12392 & 6160 \\
\hline 3 & 41 & $M$ & IgAN & 15.0 & 1.20 & 1.20 & 49 & 51 & 2400 & 172 \\
\hline 4 & 40 & $M$ & MGN & 16.0 & 1.20 & 1.20 & 30 & 41 & 8588 & 1560 \\
\hline 5 & 36 & $M$ & MPGN & 13.1 & 1.07 & 1.10 & 45 & 49 & 2927 & 1350 \\
\hline
\end{tabular}

$A T$ - after treatment, BT-before treatment, F-female, GN-glomerulonephritis, Hb-hemoglobin, IgAN-IgA nephropathy, $M-$ male, MGN-membranous glomerulonephritis, MPGN - membranoproliferative glomerulonephritis 


\section{Discussion}

We are of the opinion that HP eradication therapy significantly increases serum albumin levels in primary glomerulonephritis patients with dyspeptic complaints and HP positive upper gastrointestinal system pathology. The increase in serum albumin values may be attributed to the overall improvement ensured with the treatment of HP, an antigen which triggers the development of glomerulonephritis, or the improvement of appetite after HP eradication therapy caused by the elimination of dyspeptic complaints in patients with glomerulonephritis.

There are limited data supporting that HP eradication has a positive effect on proteinuria and that HP may be responsible for the pathogenesis of glomerulonephritis [15-18]. Kusano et al. studied HP prevalence in the palatine tonsils of patients with recurrent pharyngotonsillitis and IgAN, and concluded that HP may play a role in the antigenic stimulation which may cause IgA nephropathy [16]. In a similar study conducted with IgAN patients, mucosal inflammation dependent on HP was shown to have the potential to stimulate systemic antibody response [17]. Nagashima et al. examined the existence of HP with immunohistochemical labeling in the renal biopsy materials of 16 patients with MGN. They found that 7 of the MGN patients had granular deposits along the glomerular capillary walls and these reacted positively with HP specific antibody. The results suggested that HP infection may be involved in the pathogenesis of MGN [18]. In this study, we obtained an increase in serum albumin values and a decrease in proteinuria with HP eradication treatment. In spite of a statistically significant increase in the values of serum albumin, the decrease in proteinuria was not significant. At the same time, creatinine levels were significantly increased after the treatment. This may result from the improvement of activity in daily life after the treatment or the effects of ramipril used as an antiproteinuric agent. The increase in serum albumin may have been associated with HP eradication or the improvement of dyspeptic complaints and thus increased appetite after HP eradication therapy. Five (15.1\%) of the 33 patients displayed a notable regression in proteinuria in early stages after the treatment (Table IV). Of these patients, only one had been diagnosed with MGN. Thus, we are of the opinion that it is hard to attribute the positive development after eradication in these patients to spontaneous remission. The ramipril, aspirin, low protein diet and lipid reducing treatment through the study may also have contributed to the significant drop in proteinuria. However, all patients received this therapy. The presence of patients with remission, the decrease in proteinuria, and the significant increase in serum albumin and total protein levels seem to be promising.
In case reports and the few studies conducted, there is evidence for the positive course between $\mathrm{HP}$ eradication and the remission of glomerulonephritis $[15,19]$. Sugimoto et al. obtained remission in an MGN patient who had not been previously treated by immunosuppressive therapy by using HP eradication. They stated that this result may have been induced by the low stage of MGN and the swift onset of HP eradication therapy [15]. Moriyama et al. studied HP prevalence and the effectiveness of eradication therapy on proteinuria in $32 \mathrm{MGN}$ patients who were being treated with steroid therapy and had previously received immunosuppressive therapy, and found a higher $\mathrm{HP}$ prevalence among patients with MGN and obtained full remission in 3 MGN patients [19]. Membranous glomerulonephritis diagnosis was long term in all patients included in this study, and they received different immunosuppressive therapy before and during the study. Taking into consideration the population of this study and the fact that all patients received immunosuppressive therapy, we believe that it would be faulty to reach conclusions about the relationship between HP eradication and remission by using its results. Among our patients, immunosuppressive therapy started after HP eradication. Even though we had patients' long-term follow-up (12-18 months), we are of the opinion that it is not appropriate to discuss the results pertaining to this period as the immunosuppressive therapies received during this period may have been influential in the onset of remission. At the same time, immunosuppressive therapy was not delayed in any patient as it would not be ethical or legal. Long-term follow-up might be linked with spontaneous remission as well. We believe that associating the significant increase in serum albumin and total protein and the decrease in proteinuria with HP eradication may be possible with the help of comparisons of HP existence in liver tissue before and after the therapy via tissue level biopsies.

During the course of glomerulonephritis due to heavy proteinuria and loss of gamma globulins, infectious disease frequency may increase [20]. But in our study group of glomerulonephritis, we determined similar results of HP frequency with a population with dyspeptic complaints, as $76.7 \%$ and 67.6-81.3\% [6], respectively. These results show us that there is no increase in HP frequency in patients with glomerulonephritis. In the theory of extragastrointestinal effect of HP, different local and systemic inflammatory processes have been blamed $[4,7,11]$. In the course of glomerulonephritis HP may have a role in the etiopathogenesis of diseases despite the low HP frequency. In our study although we demonstrated significant increase in serum albumin values, we could not controvert urine pro- 
teinuria decrease significantly after HP eradication treatment. Our HP prevalence was similar to the normal population too. But we know that there would be different etiologic factors that can overlap in the diseases' processes and etiopathogenesis that we could not ignore.

The major limitations of our study are the limited number of patients, limited time for follow-up after HP eradication, the failure of our design to provide clear information on long-term results, the impossibility of delaying immunosuppressive therapy in the long term due to ethical issues, and inability to show HP specific antibody existence in kidney tissue.

Our study is the first to investigate the effect of HP eradication treatment on the remission of the disease, in patients with primary glomerulonephritis and dyspeptic complaints. We suggest that HP eradication treatment has minor therapeutic effects on proteinuria and the remission of disease in patients with primary glomerulonephritis. Albumin levels can increase as a result of HP eradication therapy, and remission can be obtained in some patients. While these findings seem to suggest a relation between HP and the pathogenesis of glomerulonephritis, the lack of an accompanying decrease in proteinuria is a limitation parameter. The lack of a decrease in proteinuria does not mean that HP therapy is not effective in remission. We are of the opinion that attributing the pathogenesis of the disease to HP existence will be possible through future studies that show the existence of HP specific antibody in kidney biopsy material through immunohistochemical labeling and that reinvestigate the existence of HP through post-eradication control biopsies. However, it is obvious that this may involve ethical issues. Studies with a larger patient group may yield more specific results.

\section{Conflict of interest}

The authors declare no conflict of interest.

\section{References}

1. Cattran DC. Outcomes research in glomerulonephritis. Semin Nephrol 2003; 23: 340-54.

2. Couser WG. Pathogenesis of glomerular damage in glomerulonephritis. Nephrol Dial Transplant 1998; 13 (suppl. 1): 10-5.

3. Jennette JC, Falk RJ. Glomerular clinicopathologic syndromes. In: Primer on kidney disease. Greenberg A, Cheung AK, Falk RJ, Coffman TM, Jenette JC (eds.). Elsevier Saunders, Philadelphia 2005; 150-98.

4. Franceschi F, Gasbarrini A. Helicobacter pylori and extragastric diseases. Best Pract Res Clin Gastroenterol 2007; 21: 325-34.

5. Hopkins RJ, Girardi LS, Turney EA. Relationship between Helicobacter pylori eradication and reduced duodenal and gastric ulcer recurrence: a review. Gastroenterology 1996; 110: $1244-52$.
6. Us D, Hascelik G. Seroprevalence of Helicobacter pylori infection in an asymptomatic Turkish population. J Infect 1998; 37: 148-50.

7. Konturek SJ, Konturek PC, Pieniazek P, Bielański W. Role of Helicobacter pylori infection in extragastroduodenal disorders: introductory remarks. J Physiol Pharmacol 1999; 50: 683-94.

8. Kanbay M, Kanbay A, Boyacioglu S. Helicobacter pylori infection as a possible risk factor for respiratory system disease: a review of the literature. Respir Med 2007; 101: 203-9.

9. Russo F, Jirillo E, Clemente C, et al. Circulating cytokines and gastrin levels in asymptomatic subjects infected by Helicobacter pylori (H. pylori). Immunopharmacol Immunotoxicol 2001; 23: 13-24.

10. Bohr UR, Annibale B, Franceschi F, Roccarina D, Gasbarrini A. Extragastric manifestations of Helicobacter pylori infection; other Helicobacters. Helicobacter 2007; 12 (suppl. 1): 45-53.

11. Bodger K, Crabtree JE. Helicobacter pylori and gastric inflammation. Br Med Bull 1998; 54: 139-50.

12. Budzyński J. The favourable effect of helicobacter pylori eradication therapy in patients with recurrent angina-like chest pain and non-responsive to proton pump inhibitors - a preliminary study. Arch Med Sci 2011; 7: 73-80.

13. Beckman Coulter Synchron ${ }^{\circledR}$ Clinical Systems. Chemistry information manual. This manual is intended for use with Unicel ${ }^{\circledR}$ DxC 800. Beckman Coulter, Galway, Ireland. 2004; 12: 1-1193.

14. Hegedus O, Ryden J, Rehnberg AS, Nilsson S, Hellstrom PM. Validated accuracy of a novel urea breath test for rapid Helicobacter pylori detection and in-office analysis. Eur J Gastroenterol Hepatol 2002; 14: 513-20.

15. Sugimoto T, Furukawa T, Maeda T, Somura M, Uzu T, Kashiwagi A. Marked reduction of proteinuria after eradication of gastric Helicobacter pylori infection in a patient with membranous nephropathy: coincidental or associated? Intern Med 2007; 46: 1483-4.

16. Kusano K, Tokunaga O, Ando T, Inokuchi A. Helicobacter pylori in the palatine tonsils of patients with IgA nephropathy compared with those of patients with recurrent pharyngotonsillitis. Hum Pathol 2007; 38: 1788-97.

17. Barratt J, Bailey EM, Buck KS, et al. Exaggerated systemic antibody response to mucosal Helicobacter pylori infection in IgA nephropathy. Am J Kidney Dis 1999; 33: 1049-57.

18. Nagashima R, Maeda K, Yuda F, Kudo K, Saitoh M, Takahashi T. Helicobacter pylori antigen in the glomeruli of patients with membranous nephropathy. Virchows Arch 1997; 431: 235-9.

19. Moriyama T, Kaneko T, Fujii M, Tsubakihara Y, Kawano S, Imai E. High prevalence of Helicobacter pylori infection in Japanese patients with membranous nephropathy. Aliment Pharmacol Ther 2006; 24 (suppl. 4): 189-93.

20. Floege J, Feehally J. Introduction to glomerular disease: clinical presentations. In: Comprehensive clinical nephrology. Feehally J, Floege J, Johnson RJ (eds.). Mosby, Philadelphia 2007; 193-208. 